\title{
Effectiveness of application alternative drive vehicles in public transport
}

\author{
Tadeusz Dyr ${ }^{1,}$, Karolina Ziółkowska², Przemysław Misiurski ${ }^{3}$, and Małgorzata Kozłowska ${ }^{1}$ \\ ${ }^{1}$ University of Technology and Humanities in Radom, Faculty of Economic and Legal Sciences, Radom, Poland \\ ${ }^{2}$ University of Social Sciences in Lodz, Lodz, Poland \\ ${ }^{3}$ Opole University of Technology, Faculty of Economics and Management, Opole, Poland
}

\begin{abstract}
European transport policy for the first half the 21 st century assumes creating the transport system organised with the respect of the principle of sustainable development, providing economic, social and ecological needs of the society and supporting construction of the integrated society and entirely integrated and competitive Europe. Applying alternative fuels and drives in public transport vehicles, including the development of electric-powered vehicles is an essential instrument of this policy. In the paper fuels applied in the public transport and alternative drives were described. Methodological establishments of evaluation of the investment's financial and economical effectiveness associated with acquiring public means of transport with the alternative drive were discussed. Using the method of the econometric modelling, operational and maintenance costs of use buses with the conventional and alternative drive were described. They constitute the basis of assessment of the financial effectiveness of replacing conventional vehicles with alternative propulsion vehicles. They pointed to benefits resulting from limiting the influence of public transport using alternative propulsion vehicles on the natural environment. They find expression in decreasing transport's external expenses, confirming the economic effectiveness of their application. A special attention was paid on vehicles with the electric propulsion. Their application in the urban transport is a crucial factor of improvement of the air quality in cities. Based on conducted examinations it was pointed at the purpose of applying means of transport with the alternative drive.
\end{abstract}

\section{Introduction}

The consistent increase in the level of urbanization effects both positive and negative. Strongly urbanised areas support the development of knowledge, learning and technology. It results above all from the great accretion of the idea on relatively small area [13], becoming a crucial factor of competitiveness and the growth in the economy of states and regions [18].

Adverse effects of the urbanization are related, among other things, to municipal transport systems. Meeting the transport needs takes place largely at using passenger cars and buses with conventional drive. Tis leads to emissions of harmful substances, including greenhouse gases, increase of the congestion and highrisk communications accidents [3]. The high share of vehicles driven with petroleum-derived fuels also causes existence of significant deficit in the trade balance of around $2.5 \%$ GDP of the EU member states [2]. An instrument of preventing these risks is an alternative transport fuels strategy in the sector of European Union transport [17]. Such an assumption was also adopted in Polish energy policies to 2050 [15].

At the public transport in Poland, according Central Statistical Office of Poland data from December 31,2016, 11973 buses, 3332 trams and 223 trolleybuses were used . Enterprises of the public transport operated
454 buses with alternative drives $(3.8 \%$ of total number of buses). Buses fuelled by compressed natural gas (CNG), constituting c $70 \%$ of buses fuelled by alternative fuels have a dominating significance. Including the additional purchase of 40 hybrid buses (gas-electric) in 2015 for the purposes of the public transport in Częstochowa and 35 LNG buses in Warsaw, the participation of buses fuelled by natural gas in the total number of buses with alternative drives amounts in Poland around 95\%. In 2017 a few supplies of electric buses were carried out to Polish cities, and a few cities announced public tenders for the delivery of such buses. However the participation of buses with alternative fuels must be qualified as very low. It is possible to put the following research question: why - in spite of the possibility of limiting the negative impact on the environment and for support in achieving the goals of the sustainable development - the share of vehicles with alternative drives is so low? The article constitutes the attempt of the reply to the question. Conducted examinations point, that the base of investment decisions realized by the public transport enterprises and local governments responsible for organization and financing the public transport, including the type of buses' engine types, are evaluation results of the financial and economic effectiveness.

\footnotetext{
* Corresponding author: t.dyr@uthrad.pl
} 


\section{Introduction}

The possibility of using fuels and alternative drives depends on the transport kind and distance and the means of transport. The greatest possibilities of using different fuels appeare on urban areas (Table 1).
Applying fuels and alternative drives is a crucial factor of limiting the adverse impact of the transport to the environment and the counteraction for climate change. The literature review confirms that replacing buses with diesel engines with vehicles with the alternative drive generates high social benefits. And so such investments should be supported from public means.

Table 1. Coverage of transport modes and travel range by the main alternative fuels [2].

\begin{tabular}{|c|c|c|c|c|c|c|c|c|c|c|c|c|}
\hline \multirow{4}{*}{\multicolumn{2}{|c|}{ Fuel/drive }} & \multicolumn{11}{|c|}{ Transport mode } \\
\hline & & \multicolumn{6}{|c|}{ Road } & \multirow{3}{*}{ Air } & \multirow{3}{*}{ Rail } & \multicolumn{3}{|c|}{ Water } \\
\hline & & \multirow{2}{*}{\multicolumn{3}{|c|}{ Passenger }} & \multicolumn{3}{|c|}{ Freight } & & & \multirow{2}{*}{ inland } & \multirow{2}{*}{ short-sea } & \multirow{2}{*}{ maritime } \\
\hline & & short & & & short & medium & long & & & & & \\
\hline \multicolumn{13}{|l|}{ LPG } \\
\hline Natural & $\mathrm{LNG}$ & & & & & & & & & & & \\
\hline Gas & $\mathrm{CNO}$ & & & & & & & & & & & \\
\hline \multicolumn{13}{|c|}{\begin{tabular}{|l} 
Electricity \\
\end{tabular}} \\
\hline \multicolumn{13}{|c|}{ Biofuels (luiquid) } \\
\hline Hydrogen & & & & & & & & & & & & \\
\hline
\end{tabular}

Amongst available alternative fuels a natural gas is of special importance. Using it is a crucial factor of the improvement in the quality of air in cities [10]. This fuel is recognised as the cleanest and the most hydrogen-rich hydrocarbon energy sources [6]. Using the natural gas both in the form of compressed natural gas (CNG), as well as liquid natural gas (LNG) - is a crucial factor of achieving purposes of the sustainable development [1]. Vehicles fuelled with the natural gas produce significantly less toxic sub-stances and greenhouse gases, particularly $\mathrm{CO}_{2}$, than vehicles with Diesel drives.

Using hydrogen is perceived as the essential instrument of the improvement in the energy security and the reduction in greenhouse gases. It may be used as the transport fuel and energy-storage agent [22]. Conducted examinations show that using this fuel in fuel cells is the most effective [23]. High costs of fuel cells and lack of refuelling infra-structure network are the main problems of applying hydrogen, as fuel to the drive of vehicles. However the permanent technological progress causes the systematic efficiency improvement of their application [11].

In recent years at the public transport electric buses have had a greater significance. In 2016 Solaris Urbino 12 electric bus, the first electric bus, was rewarded with the Bus of the Year 2017 title [19].

A major advantage of electric buses is their lowenergy consumption and zero emission in the place of providing the transport services [12]. Their main defect is relatively high investments associated with the purchase of buses and loading infra-structure. Usually there needs to be higher amount of electric buses than the diesel buses to do identical transport tasks [14].

\section{Methodology}

Taking investment decisions, regarding the type of the drive in public transport vehicles includes results of the evaluation of the financial and economic effectiveness. After initial recognition this evaluation is conducted from investor's point of view, concentrating on the cash flow generated by the project in the transport enterprise. In the second recognition additional external costs and benefits are included [4]. They include these costs and benefits which are associated with production and consumption which are incurred by entities notparticipating directly in the production, consumption or the exchange of the given good. In consequence that leads to necessity of bearing by these entities certain extra costs for which they don't receive any compensation from their perpetrator. It can also cause them benefits for which they don't pay the salary [20]. These costs and benefits determine accidental or incidental results of the entities' intentional activities. These include expressed in money negative effects of activity, including transport, to the natural environment [21].

Algorithm of financial effectiveness evaluation of investment projects, including purchase of public transport vehicles is presented in Figure 1. Financial effectiveness analysis is aimed to verify whether the project needs co-financing from public funds. And the economic effectiveness analysis should allow obtaining the answer to a question whether the project is worth cofinancing. Algorithm of financial effectiveness evaluation of investment projects, including purchase of public transport vehicles is presented in chart 1 , and the economic one in Figure 2.

In the evaluation of investment effectiveness incremental method is used (Sartori et al., 2014). Applying this method allows to make independent calculations from costs unrelated to vehicle's drive kind, i.e. costs which are identical for buses with different drives and aren't affecting effectivenesses evaluation results.

In incremental method it is necessary to identify cash flows diversifying compared investment variants. In the financial analysis these are investment costs, fuel costs and maintenance costs. In the economic analysis, apart from mentioned ones, external benefits are included. 


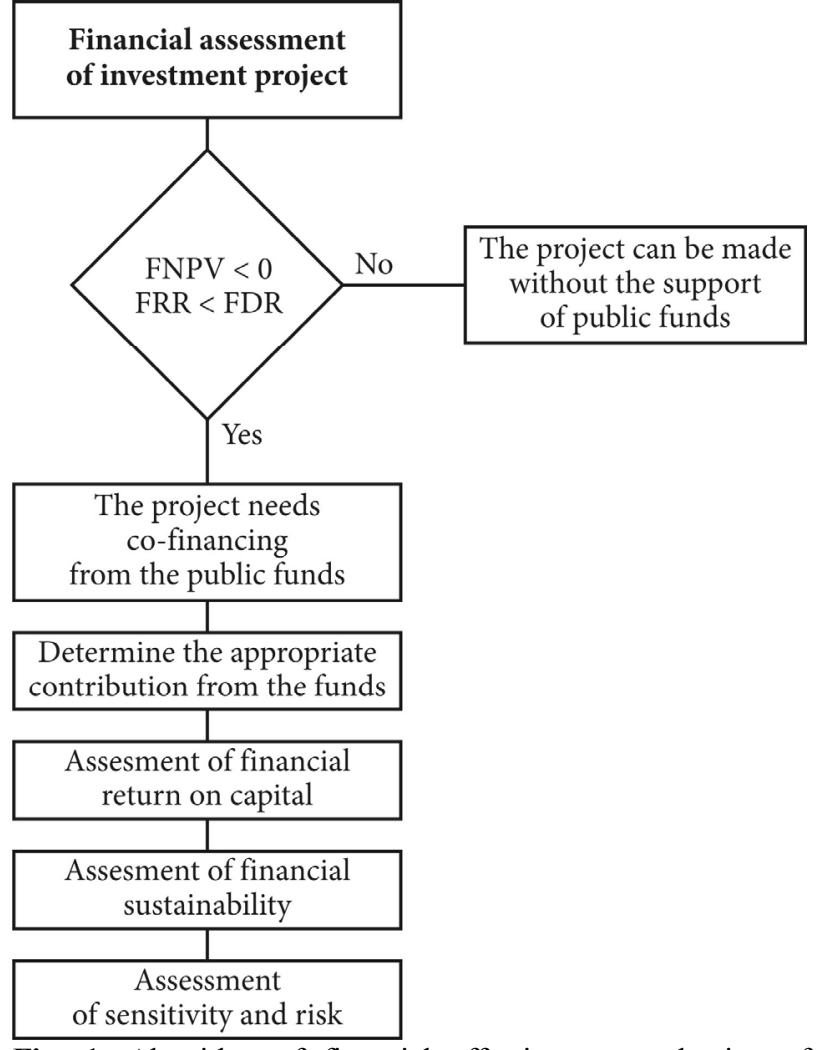

Fig. 1. Algorithm of financial effectiveness evaluation of investment projects.

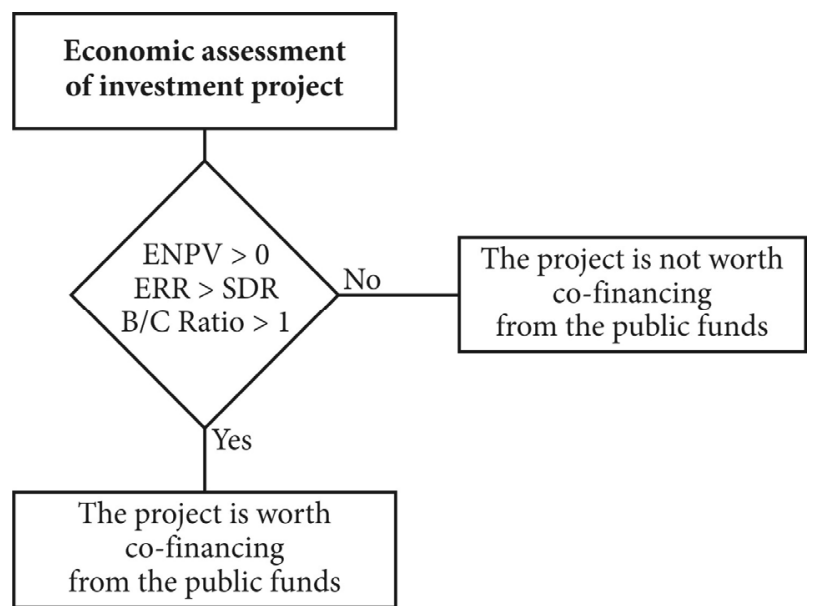

Fig. 2. Algorithm of economic effectiveness evaluation of investment projects.

\section{Financial costs and benefits of purchasing buses with the alternative drive}

A significant influence on the level of investments has a type of the drive. For buses with the length of $12 \mathrm{~m}$ they amount:

- Diesel bus - 825 thous. PLN,

- CNG Bus - 1030 thous. PLN,

- Hybrid bus - 1250 thous. PLN,

- Electric bus - 2100 thous. PLN

Investment costs difference leads to diversity of depreciation amounts. However this component of costs isn't taken into account in the calculation of efficiency indicators. In this calculation only cash flows are taken into account [7]. However it has a significant influence on amount of compensation paid to the operator. According to Regulation (EC) No 1370/2007 [16] to service costs, constituting the basis of the compensation setting, include among others the depreciation costs. Application of $\mathrm{CNG}$ buses is a factor increasing expenses of self-government bodies on financing public transport services.

The factor that diversifies the effectiveness of replacing Diesel buses into vehicles with the alternative drive are costs of consuming fuels and the energy. Statistical data collected in examined enterprises show that the size of consuming diesel, the natural gas and the electric energy is identical in the entire life cycle of the vehicle. Hesitations in the level of the fuel consumption and the energy result mainly from weather conditions (using the air-conditioning or warming) and line load (number of passengers in the bus). In this situation for further analysis average costs of the fuel consumption of all inspected buses were taken. They amount:

- Diesel bus - 138,5 PLN/100 km (38,6 1/100 km),

- CNG Bus - 124,1 PLN/100 km (49,2 m³/100 km),

- Hybrid bus - 110,0 PLN/100 km (31 1/100 km),

- Electric bus - 60,0 PLN/100 (200 kWh/100 km).

Maintenance costs are a crucial factor determining the effectiveness of purchasing the public transport vehicles. The relatively short operating period of hybrid and electric buses reduces precise determination of these costs in the entire life cycle. On that account the comparison was conducted for two types of buses $\mathrm{CNG}$ and electric ones. For the comparison primary data from two enterprises exploiting c 130 buses were used. Conducted examinations show that the use of buses from the moment of the purchase causes gradual increase of renovations and maintenance costs. Their amount depends on the total bus mileage and the drive type. Evolution of the costs was presented in picture 3. Base of drawing the curve of costs are results of the econometric modelling. In the model a relation of unit running costs of the bus's availability being a sum of spare parts and repairs costs (dependent variable) from the accumulated mileage, reflecting the level of the vehicle's technical use (explanatory variable) was set [5].

As a consequence of faster growth of average maintenance costs of $\mathrm{CNG}$ buses there is an increasing difference between total maintenance costs of $\mathrm{CNG}$ and diesel buses (Figure 3). This component of operating cost is usually omitted in analyses. Meanwhile it has a significant influence on the financial effectiveness of purchasing CNG buses. Higher maintenance costs cause decrease of operating benefits resulting from lowest costs of fuel consumption.

Presented incremental cahs flow allows for the comparison of effectivenesses of applying buses fuelled by compressed natural gas and diesel at the public transport. Net present value indicator was used for the evaluation. For calculations of efficiency indicators discount rate in value of $4 \%$, and time horizon -10 years were used. It was assumed that a bus would be purchased in year 0 . These values are recommended by 
experts of the Jaspers initiative for investment projects in the public transport carried out in Polish cities cofinanced from funds of the European Union [9].

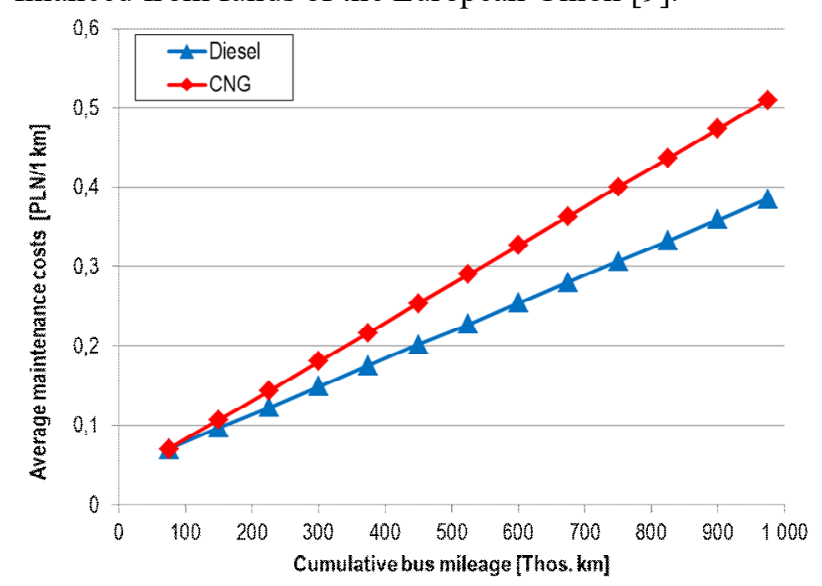

Fig. 3. Maintenance costs Diesel and CNG buses.

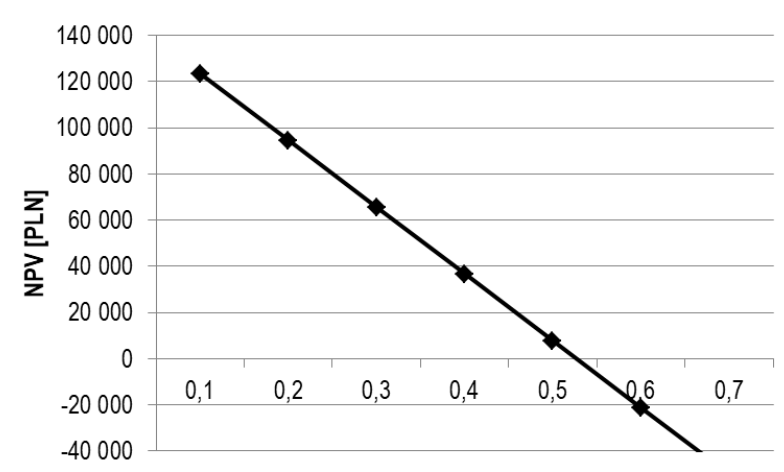

Fig. 4. Comparing the effectiveness of the purchase of the CNG and diesel bus depending on the relation of the fuels' price.

The NPV value was appointed in the function of the relation of $1 \mathrm{~m}^{3} \mathrm{CNG}$ and $1 \mathrm{dm}^{3}$ of diesel price. Results of calculations were presented in Figure 4. They show that the purchase of the CNG bus is more effective, if the price doesn't exceed $57.1 \%$ of price of $1 \mathrm{~m}^{3} \mathrm{CNG} 1 \mathrm{dm}^{3}$ of diesel. Otherwise for a transport enterprise purchasing a bus with the diesel drive is more profitable.

Presented analysis results assumes invariability of investment costs and maintenance cost. In reality these costs can change. Their height is determined by microand macroeconomic factors. Consequence of these changes can be other than appointed border value of the relation of CNG to diesel fuel's price. Sensitivity analysis reflects the assessment of such changes impact. Conducted calculations' results show that the border value of $1 \mathrm{~m}^{3} \mathrm{CNG}$ price should not cross $52 \%$ of $1 \mathrm{dm}^{3}$ diesel fuel. Exceeding this border is leading to the financial unprofitability of purchasing $\mathrm{CNG}$ buses.

Relatively little mileage of electric and hybrid buses exploited by the public transport enterprises in Poland is limiting, as already recalled, evaluation of the financial effectiveness of applying vehicles with these drives. Considering only 2 variables - investment costs and energy consumption cost a mileage, by which these costs will be levelled was appointed. They amount:

- Hybrid bus - 1,4 mln km,

- Electric bus - 1,6 mln km.
Drawn values are outside the boundary of profitable economically use of Diesel buses. Probably using hybrid and electric buses at such a course also will be unprofitable . It points out to the need of supporting investment from public means. Buses with alternative drives are characterized by a much lower negative impact on the environment. According to examinations conducted in the Motor Transport Institute in Warsaw [8], CNG application on the public transport buses causes reduction of discharges of toxic or otherwise polluting substances in the comparison from Diesel Bus with the Euro 6 engine, including $\mathrm{CO}_{2}$ of about $25 \%, \mathrm{CO}$ of about $50 \%$, NOx of about $90 \%$ and PM - almost by the $100 \%$.

In case of electric buses emission of toxic substances is entirely eliminated. In consequence in comparison with Euro 6 bus in the entire life cycle (mileage of 1 million $\mathrm{km}$ ) reduces:

- greenhouse gas emission - for about $670 \mathrm{~kg}$,

- particulates - for about $50 \mathrm{~kg}$.

For CNG buses the reduction amounts:

- greenhouse gas emission - for about $380 \mathrm{~kg}$,

- particulates - for about $50 \mathrm{~kg}$.

Described environmental benefits confirm usefulness of applying buses with alternative drives at the public transport. These vehicles also enable a significant limitation of noise, smog and carcinogens.

\section{Conclusions}

Implementing the idea of the sustainable development is connected among others with the broader exploitation of alternative fuels in the transport sector, including coming from renewables. It is of special importance, how results from the conducted literature review, in cities and the urbanized area. The transport sector is there a main issuer of harmful substances, including greenhouse gases.

Barrier for the wide application of buses with alternative drive are higher investment costs than in case of purchasing diesel buses and uncertainty connected with operating costs of these vehicles, in it with costs of fuel and energy consumption. In many cases a need to adapt technical and service facilities for operating vehicles with alternative drives is also essential. In consequence applying buses with alternative drives is perceived by managers of transport enterprises, as the solution burdened with relatively high risk.

The European Union policy assuming creation of resource efficient transport system and friendly to the natural environment is a chance to increase the use of alternative fuels at the public transport. Increase in supporting investment in the communication including the purchase of low-emission vehicles is a consequence of this policy. Also there is an increase in environmental awareness of residents leading to higher interests in using environment-friendly means of transport. 


\section{References}

1. Brito TLF, Moutinho dos Santos E., Galbieri R., Costa HK de M., Qualitative Comparative Analysis of cities that introduced compressed natural gas to their urban bus fleet, Renew Sustain Energy Rev. 71, 502-508 (2016) doi: 10.1016/j.rser.2016.12.077

2. COM 17, Clean Power for Transport: A European alternative fuels strategy (2013)

3. COM 913, Together towards competitive and resource-efficient urban mobility (2013)

4. T. Dyr, P.R. Kozubek, Assessment of transport infrastructure investments co-financed from European Union funds (Spatium, Radom, Poland, 2013) [in Polish]

5. T. Dyr, P. Misiurski Forecasting of costs of maintenace and use of a bus fleet. Transp. Logist. Probl., 35, 19-28 (2016) doi: 10.18276/ptl.2016.3502 [in Polish]

6. M.J. Economides, D.A. Wood, The state of natural gas. J Nat Gas Sci Eng, 1, 1-13 (2009) doi: 10.1016/j.jngse.2009.03.005

7. M. Florio, Applied Welfare Economics: CostBenefit Analysis of Projects and Policies (Routledge, New York, 2014)

8. W. Gis, E. Menes, J. Waśkiewicz. Natural gas fuels in urban transport in Poland, Transp Samoch (2011) [in Polish]

9. JASPERS, Blue Book. Public Transport sector in cities, agglomerations, regions (Warsaw, 2015)

10. G. Karavalakis, M. Hajbabaei, Y. Jiang, J. Yang, K. C. Johnson, D. R. Cocker, T. D. Durbin, Regulated, greenhouse gas, and particulate emissions from lean-burn and stoichiometric natural gas heavyduty vehicles on different fuel compositions, Fuel, 175, 146-156 (2016) doi: 10.1016/j.fuel.2016.02.034

11. A. Lajunen, Fuel economy analysis of conventional and hybrid heavy vehicle combinations over realworld operating routes. Transp Res Part D: Transport and Environment, 31, 70-84 (2014) doi: 10.1016/j.trd.2014.05.023

12. A. Lajunen, Energy consumption and cost-benefit analysis of hybrid and electric city buses. Transp Res Part C: Emerging Technologies, 38, 1-15 (2014) doi: 10.1016/j.trc.2013.10.008

13. V. Maráková, T. Dyr, A. Wolak-Tuzimek, Factors of tourism's competitiveness in the European Union countries, Ekonomika a management, 19, 92-109 (2016) doi: 10.15240/tul/001/2016-3-007

14. J. Miles, S. Potter, Developing a viable electric bus service: The Milton Keynes demonstration project. Res Transp Econ, 48, 357-363 (2014) doi: 10.1016/j.retrec.2014.09.063

15. Ministry of Energy, The project of Poland's Energy Policy until 2050 (Warsaw, 2015)

16. OJ L 315 3.12.2007 Regulation (EC) No $1370 / 2007$ of the European Parliament and of the Council of 23 October 2007 on public passenger transport services by rail and by road and repealing Council Regulations (EEC) Nos 1191/69 and 1107/70 (2007)

17. K. Romejko, M. Nakano, Portfolio analysis of alternative fuel vehicles considering technological advancement, energy security and policy. J Clean Prod, 142, 39-49 (2017) doi: 10.1016/j.jclepro.2016.09.029

18. P.M. Romer, Endogenous Technological Change. J Polit Econ, 98, 71-102 (1990) doi: 10.1086/261725

19. Z. Rusak, Title International Bus of the Year for new Solarius Urbino electric, Autobusy - Tech Eksploat Syst Transp, 12-20 (2016) [in Polish]

20. J.E. Stiglitz, Economics of the Public Sector, Third Edit. (W. W Norton \& Company, New York/London, 2000)

21. D. Štreimikienè, I. Mikalauskas, Internalization of external costs in Lithuania and Poland, J Int Stud, 8, 50-61 (2015) doi: 10.14254/2071-8330.2015/8$3 / 4$

22. J. Wang, Theory and practice of flow field designs for fuel cell scaling-up: A critical review. Appl Energy, 157, 640-663 (2015) doi: 10.1016/j.apenergy.2015.01.032

23. J. Wang, Barriers of scaling-up fuel cells: Cost, durability and reliability, Energy, 80, 509-521 (2015) doi: 10.1016/j.energy.2014.12.007 